\title{
A study of maternal and fetal outcome in meconium-stained amniotic fluid-a prospective hospital-based study
}

\author{
Aparna U. Dandale*, Amarjeet Kaur Bava, Nikhil R. Shinde
}

Department of Obstetrics and Gynecology, LTMMC and LTMGH, Sion, Mumbai, Maharashtra, India

Received: 20 September 2021

Accepted: 18 November 2021

\section{*Correspondence:}

Dr. Aparna U. Dandale,

E-mail: draparnad7@gmail.com

Copyright: () the author(s), publisher and licensee Medip Academy. This is an open-access article distributed under the terms of the Creative Commons Attribution Non-Commercial License, which permits unrestricted non-commercial use, distribution, and reproduction in any medium, provided the original work is properly cited.

\begin{abstract}
Background: Meconium is a collection of secretions and desquamated cells from the digestive tract, and waste products from ingested amniotic fluid. It is a viscous, dark-green substance composed of intestinal epithelial cells, lanugo, mucus, and intestinal secretions. Intra uterine passage of meconium occurs in case of fetal distress; Important causes of in utero passage of meconium are oligohydramnios, placental insufficiency, preeclampsia.

Methods: The present prospective observational study is conducted at department of obstetrics and gynecology of tertiary care centre, Lokmanya Tilak municipal medical college and hospital, Mumbai. All antenatal women attending hospital in active phase of labour who fulfilled the inclusion criteria of single term pregnancy in cephalic presentation were included. A predesigned pretested interview schedule questionnaire was prepared in accordance with study objectives and was conducted in the language which they best understood. Permission was obtained from the institutional ethics committee. Maternal outcome: Increased incidence of cesarean and instrumental deliveries, wound infection, post-partum hemorrhage. Perinatal outcome: Birth asphyxia, meconium aspiration syndrome (MAS), respiratory distress syndrome (RSD), septicemia.

Results: Maximum women $71 \%$ were having gestational age of 37-40 weeks. most common maternal high-risk factors were post-dated pregnancy (29\%) followed by oligohydramnios $(19 \%)$. Deliveries by caesarean section were more (71.4\%), most common indication being fetal distress (44.7\%). Perinatal complications were birth asphyxia, MAS, RDS, low Apgar score.

Conclusions: Early identification of meconium-stained amniotic fluid (MSAF) in labouring women during intrapartum monitoring and availability of operation theatre for immediate intervention is required to reduce the perinatal morbidity and mortality.
\end{abstract}

Keywords: Meconium, Oligohydramnios, Birth asphyxia

\section{INTRODUCTION}

Meconium is a collection of secretions and desquamated cells from the digestive tract, and waste products from ingested amniotic fluid. It is a viscous, dark-green substance composed of intestinal epithelial cells, lanugo, mucus, and intestinal secretions. Water being the major liquid constituent (90\%) and solid constituents (10\%) consists of intestinal secretions, mucosal cells, and solid elements of swallowed amniotic fluid, such as proteins and lipids. Unlike stool, meconium is sterile and does not contain bacteria.
It begins to appear towards the start of the second trimester and gets collected in the colon until birth. Normally, Meconium is not passed before birth. Intra uterine passage of meconium occurs in case of fetal distress. Important causes of in utero passage of meconium are oligohydramnios, placental insufficiency, preeclampsia, and maternal drug abuse, especially use of tobacco and cocaine.

Passage of fresh meconium during labour may signal fetal intolerance to labour and is associated with worse neonatal 
outcome, in terms of five-minute Apgar scores $<7$ and an umbilical artery $\mathrm{pH}<7.10 .^{1}$

Meconium and its effects on fetus and neonates have remained a cause of significant worry for both the obstetrician and neonatologists. There are still widespread debates with varied opinions regarding the optimum obstetrical approach, resuscitative measures at birth and management of critically ill neonates with MAS. With the recognition of role of chronic in utero hypoxia and associated perinatal asphyxia in pathogenesis of MAS, routine endotracheal suctioning is no longer recommended even in non-vigorous infants with MAS. Advent of newer therapies like inhaled no, surfactant, high-frequency ventilation and extracorporeal membrane oxygenation (ECMO) has resulted in tremendous improvements in MAS survival. ${ }^{2}$

\section{Pathogenesis of meconium passage in amniotic fluid}

Meconium begins to appear in the fetal intestines by the $10^{\text {th }}$ week of life gradually increasing in amount to reach $200 \mathrm{gm}$ at birth.

Lucas et al suggested that levels of "motilin" an intestinal hormone responsible for bowel peristalsis and defecation are lower in premature infants and higher in those who have passed meconium. It has been shown that infants with fetal distress had a four-fold elevation of cord plasma Motilin than normal. ${ }^{3}$

Meconium passage is rare before term because of lack of integrated parasympathetic system which is stimulated by in utero hypoxia and acidosis leading increased peristalsis and relaxed anal sphincter causing meconium passage. Animal experiments shows that hypoxia causes deep intrauterine gasping and risk for aspiration. ${ }^{4}$

Walker observed that Meconium appears as a result of interference with trans-placental transfer of oxygen. Critical oxygen level of umbilical venous blood was $30 \%$ or lower than fetus at term. ${ }^{5}$

Desmond agreed with the Walker theory which postulated that:

Hypoxia $\rightarrow$ reflex vagal stimulation $\rightarrow$ relaxation of anal sphincter $\rightarrow$ meconium passage

Factors that promote the passage of meconium in utero include the following: Pregnancy that lasts longer than 42 weeks or longer, secondary to a hypoxic stress, placental insufficiency, transient rise of $\mathrm{pCO}_{2}$ or fall in the $\mathrm{pO}_{2}$ in the umbilical arteries due to pressure in the umbilical cord without metabolic acidosis, maternal hypertension, preeclampsia, oligohydramnios, maternal drug abuse, especially of tobacco and cocaine, fetal distress during labour, transient pressure on the scalp during labour, amnionitis and iodiopathic.., 7

\section{Objectives}

\section{Primary objective}

The primary objectives were to find the association of comorbidities in fetus who passed meconium in utero and to study fetomaternal risk factors associated with meconium passage in utero.

\section{Secondary objective}

Secondary objectives were to evaluate fetal outcomes in meconium-stained liquor.

\section{METHODS}

\section{Study design}

The study design was of hospital based prospective observational study

\section{Study place}

This study done in department of obstetrics and gynecology at Lokmanya Tilak municipal medical college and hospital, Sion, Mumbai, Maharashtra.

\section{Study period}

Study conducted from November 2017 to August 2019.

\section{Sample size}

The 200 patients were participated in the study.

\section{Sampling unit}

All antenatal women patients attending at our tertiary care centre in the department of obstetrics and gynecology in active phase of labour who fulfilled the inclusion criteria.

\section{Selection criteria of patients}

\section{Inclusion criteria}

Those who were willing to participate, 37 weeks gestation, Single term pregnancy, cephalic presentation, liquor meconium stained and women in active phase of labour were included in the study.

\section{Exclusion criteria}

Those who had pre-term delivery, breech presentation and multiple pregnancies were excluded from the study.

A predesigned pretested interview schedule questionnaire was prepared in accordance with study objectives. The questionnaire was prepared in English and interview was conducted in the language which they best understood. 
The structured questionnaire was subjected for face and content validation by the department of obstetrics and gynecology. Permission to conduct the study and ethical clearance was obtained from the institutional ethics committee. Participants were fully informed about the purpose, procedures, and benefits of participation in the study through informed consent form. Participation in this study was voluntary. Participants were informed that all record pertaining to the study would be confidential, and that numbers instead of names would be used to identify the participants and data would be used for academic purpose only. Pre-tested questionnaire. Detailed history of mothers was recorded with emphasis on antepartum and intra-partum risk factors like medical disorders, obstetric complications, etc. Consistency of meconium was divided into, thick and moderate. Thick meconium was characterised by opaque and deep green coloured liquor whereas opalescent liquor with colour in between deep green and light-yellow green represents moderate meconium. Decision of mode of delivery was taken depending on stage of labour, FHR pattern, availability of operational theatre (OT), consent of patients and relatives. Amnioinfusion was done in patients with active and transition phase of labour with prophylactic antibiotic coverage. Maternal outcome in terms of mode of delivery and puerperal complications were recorded.

Individualised outcome of MSAF babies were noted with special emphasis on factors like Apgar score, need of resuscitation, duration of NICU stay, complications etc. Morbidity of neonates were noted with emphasis on MAS, RDS, hypoxic ischaemic encephalopathy (HIE), birth asphyxia, NICU admission, sepsis etc. Maternal and perinatal mortality was evaluated.

\section{Operational definitions}

Operational definitions were-active phase of labour: cervical dilatation $5-7 \mathrm{~cm}$ and transition phase of labour: cervical dilatation $>8 \mathrm{~cm}^{8}$

\section{RESULTS}

\section{Proportion of MSAF in present study}

In center, 9821 deliveries were conducted from November 2017 to August 2019 out of which 1287 (13.11\%) deliveries had MSAF. In this study that $112(56 \%)$ patients had thick MSAF while 88 (44\%) patients had moderate.

Table 1: Distribution of patients according to gestational age at delivery.

\begin{tabular}{|c|c|c|c|c|c|c|}
\hline \multirow{2}{*}{$\begin{array}{l}\text { Gestational } \\
\text { age at } \\
\text { delivery } \\
\text { (Weeks) }\end{array}$} & \multicolumn{2}{|c|}{$\begin{array}{l}\text { Thick, } \\
(\mathrm{n}=112)\end{array}$} & \multicolumn{2}{|c|}{$\begin{array}{l}\text { Moderate, } \\
(\mathrm{n}=\mathbf{8 8})\end{array}$} & \multicolumn{2}{|c|}{$\begin{array}{l}\text { Total, } \\
(\mathrm{n}=\mathbf{2 0 0})\end{array}$} \\
\hline & $\mathbf{N}$ & $\%$ & $\mathbf{N}$ & $\%$ & $\mathbf{N}$ & $\%$ \\
\hline $37-40$ & 80 & 71.4 & 62 & 70.4 & 142 & 71 \\
\hline$>40$ & 32 & 28.5 & 26 & 29.5 & 58 & 29 \\
\hline Total & 112 & 100 & 88 & 100 & 200 & 100 \\
\hline
\end{tabular}

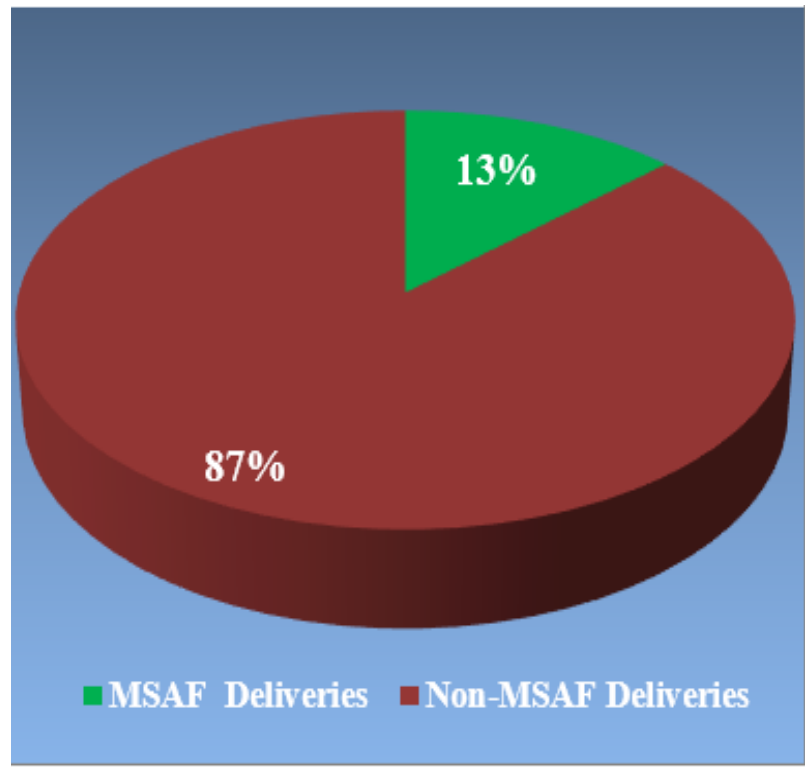

Figure 1: Proportion of MSAF in present study.

In above table, out of 142 patients, $80(71.4 \%)$ patients had thick MSAF and $62(70.4 \%)$ patients had moderate MSAF with gestational age of 37 to 40 weeks. After 40 weeks of gestation $32(28.5 \%)$ patients had thick MSAF while 26 (29.5\%) patients had moderate MSAF.

Table 2: Maternal risk factors in patients with MSAF, $(\mathbf{n}=\mathbf{2 0 0})$.

\begin{tabular}{|c|c|c|c|c|c|c|}
\hline \multirow{2}{*}{$\begin{array}{l}\text { Maternal risk } \\
\text { factors } \\
\text { associated } \\
\text { with MSAF }\end{array}$} & \multicolumn{2}{|c|}{$\begin{array}{l}\text { Thick, } \\
(\mathrm{n}=112)\end{array}$} & \multicolumn{2}{|c|}{$\begin{array}{l}\text { Moderate, } \\
(\mathrm{n}=\mathbf{8 8})\end{array}$} & \multicolumn{2}{|c|}{$\begin{array}{l}\text { Total, } \\
(\mathrm{n}=\mathbf{2 0 0})\end{array}$} \\
\hline & $\mathbf{N}$ & $\%$ & $\mathbf{N}$ & $\%$ & $\mathbf{N}$ & $\%$ \\
\hline $\begin{array}{l}\text { Postdate } \\
\text { pregnancy }\end{array}$ & 32 & 28.5 & 26 & 29.5 & 58 & 29 \\
\hline $\begin{array}{l}\text { Oligohydram } \\
\text { nios }\end{array}$ & 23 & 20.5 & 15 & 17 & 38 & 19 \\
\hline PIH & 21 & 18.7 & 12 & 13.6 & 33 & 16.5 \\
\hline Anemia & 8 & 7.1 & 6 & 6.8 & 14 & 7 \\
\hline PROM & 6 & 5.3 & 4 & 4.5 & 10 & 5 \\
\hline $\begin{array}{l}\text { Antepartum } \\
\text { hemorrhage }\end{array}$ & 4 & 3.5 & 0 & 0 & 4 & 2 \\
\hline $\begin{array}{l}\text { Total no. of } \\
\text { maternal } \\
\text { complications }\end{array}$ & 94 & 83.9 & 63 & 71.5 & 157 & 78.5 \\
\hline
\end{tabular}

In this study, 94 (83.9\%) mothers of thick meconium and $63(71.5 \%)$ of moderate meconium were having maternal high-risk factors. Overall (i.e., in thick and moderate Meconium) most common maternal high-risk factors was post-dated pregnancy $58 \quad(29 \%)$ followed by oligohydramnios 38 (19\%), pregnancy induced hypertension 33 (16.5), anaemia 14 (7\%), PROM $10(5 \%)$, antepartum haemorrhage $4(2 \%)$ consisting of abruption placenta 3 , placenta previa 1 . 
Table 3: Distribution of patients according to dilatation of cervix at the time of detection of meconium.

\begin{tabular}{|lllllll|}
\hline $\begin{array}{l}\text { Stage of } \\
\text { labour }\end{array}$ & \multicolumn{2}{l}{$\begin{array}{l}\text { Thick, } \\
(\mathbf{n}=\mathbf{1 1 2})\end{array}$} & \multicolumn{2}{l}{$\begin{array}{l}\text { Moderate, } \\
(\mathbf{n}=\mathbf{8 8})\end{array}$} & \multicolumn{2}{l}{$\begin{array}{l}\text { Total, } \\
(\mathbf{n}=200)\end{array}$} \\
\hline $\begin{array}{l}\text { Active } \\
\text { phase }\end{array}$ & 68 & 60.7 & 47 & 53.4 & 115 & 57.5 \\
$\begin{array}{l}\text { Transition } \\
\text { phase }\end{array}$ & 44 & 39.2 & 41 & 46.5 & 85 & 42.5 \\
\hline Total & 112 & 100 & 88 & 100 & 200 & 100 \\
\hline
\end{tabular}

Above table shows patients who were in active phase of labour (before $7 \mathrm{~cm}$ dilatation of cervix) 68 (60.7\%) were found to have thick and $47(53.4 \%)$ moderate MSAF. In patients who crossed $8 \mathrm{~cm}$ dilatation of cervix, $44(39.2 \%)$ were found to be with thick MSAF and 41 (46.5\%) were with moderate MSAF.

Table 4: Distribution of patients according to amnioinfusion.

\begin{tabular}{|c|c|c|c|c|c|c|}
\hline \multirow{2}{*}{$\begin{array}{l}\text { Amnioin- } \\
\text { fusion }\end{array}$} & \multicolumn{2}{|c|}{$\begin{array}{l}\text { Thick, } \\
\text { (n=112) }\end{array}$} & \multicolumn{2}{|c|}{$\begin{array}{l}\text { Moderate, } \\
(\mathrm{n}=\mathbf{8 8})\end{array}$} & \multicolumn{2}{|c|}{$\begin{array}{l}\text { Total, } \\
(n=200)\end{array}$} \\
\hline & $\mathbf{N}$ & $\%$ & $\mathbf{N}$ & $\%$ & $\mathbf{N}$ & $\%$ \\
\hline Received & 48 & 42.8 & 28 & 31.8 & 76 & 38 \\
\hline $\begin{array}{l}\text { Not } \\
\text { received }\end{array}$ & 64 & 57.1 & 60 & 68.1 & 124 & 62 \\
\hline Total & 112 & 100 & 88 & 100 & 200 & 100 \\
\hline
\end{tabular}

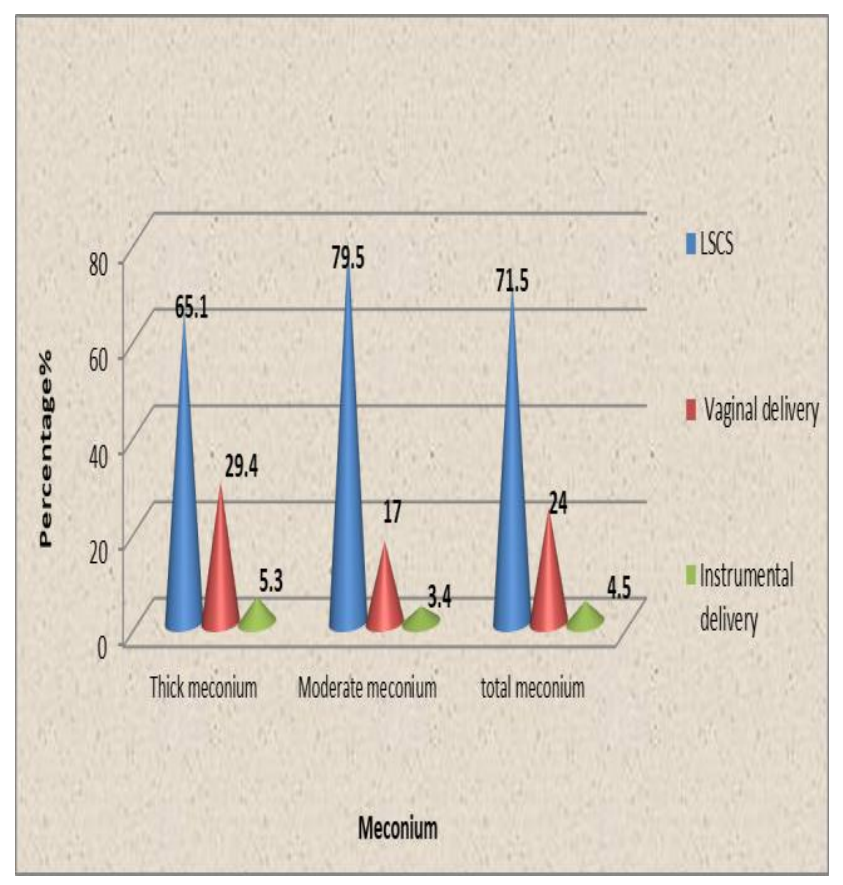

Figure 2: Distribution of patients according to mode of delivery.

In the study amnioinfusion was done in 76 patients including $48(42.8 \%)$ patients with thick MSAF and 28 $(31.8 \%)$ patients with moderate MSAF.
In our study maximum patients 143 had undergone lower segment caesarean section (LSCS) including 73 (65.1\%) patients with thick MSAF and $70(79.5 \%)$ with moderate MSAF. The $33(29.4 \%)$ patients with thick MSAF and 15 (17\%) patients with moderate MSAF had delivered normally. Instrumental delivery was conducted for 9 patients, $6(5.3 \%)$ with thick MSAF and $3(3.4 \%)$ with moderate MSAF.

Table 5: Distribution of MSAF patients according to indications for LSCS, $(n=143)$.

\begin{tabular}{|c|c|c|c|c|c|c|}
\hline \multirow{2}{*}{$\begin{array}{l}\text { Indications } \\
\text { for LSCS }\end{array}$} & \multicolumn{2}{|c|}{$\begin{array}{l}\text { Thick, } \\
(n=73)\end{array}$} & \multicolumn{2}{|c|}{$\begin{array}{l}\text { Moderate, } \\
(\mathrm{n}=70)\end{array}$} & \multicolumn{2}{|c|}{$\begin{array}{l}\text { Total, } \\
(n=143)\end{array}$} \\
\hline & $\mathbf{N}$ & $\%$ & $\mathbf{N}$ & $\%$ & $\mathbf{N}$ & $\%$ \\
\hline Fetal distress & 34 & 46.5 & 30 & 42.8 & 64 & 44.7 \\
\hline $\begin{array}{l}\text { Abnormal } \\
\text { labour }\end{array}$ & 14 & 19.1 & 15 & 21.4 & 29 & 20.3 \\
\hline $\begin{array}{l}\text { MSAF in } \\
\text { early active } \\
\text { labour }\end{array}$ & 19 & 26 & 21 & 30 & 40 & 27.9 \\
\hline $\begin{array}{l}\text { Antepartum } \\
\text { hemorrhage }\end{array}$ & 4 & 5.4 & 0 & 0 & 4 & 2.8 \\
\hline $\begin{array}{l}\text { IUGR with } \\
\text { Doppler } \\
\text { changes }\end{array}$ & 1 & 1.3 & 4 & 5.7 & 5 & 3.5 \\
\hline $\begin{array}{l}\text { Cord } \\
\text { prolapsed }\end{array}$ & 1 & 1.3 & 0 & 0 & 1 & 0.7 \\
\hline Total & 73 & 100 & 70 & 100 & 143 & 100 \\
\hline
\end{tabular}

Most common indication for LSCS was fetal distress in both meconium type i.e., $34(46.5 \%)$ in thick MSAF patients and $30(42.8 \%)$ in moderate MSAF patients, other indications being MSAF in early active labour 19 (26\%), abnormal labour $14(19.1 \%)$, antepartum haemorrhage 4 (5.4\%), IUGR with Doppler changes and cord prolapsed both were $1(1.3 \%)$. In moderate MSAF patients' other indications after fetal distress were, MSAF in early active labour 21 (30\%), abnormal labour $15(21.4 \%)$ and IUGR with Doppler changes $4(5.7 \%)$.

Table 6: Distribution of neonates according to APGAR score at 1, min, $(n=200)$.

\begin{tabular}{|c|c|c|c|c|c|c|}
\hline \multirow{2}{*}{$\begin{array}{l}\text { APGAR } \\
\text { score at } 1 \\
\text { min }\end{array}$} & \multicolumn{2}{|c|}{$\begin{array}{l}\text { Thick, } \\
(n=112)\end{array}$} & \multicolumn{2}{|c|}{$\begin{array}{l}\text { Moderate, } \\
(\mathrm{n}=\mathbf{8 8})\end{array}$} & \multicolumn{2}{|c|}{$\begin{array}{l}\text { Total, } \\
(n=200)\end{array}$} \\
\hline & $\mathbf{N}$ & $\%$ & $\mathbf{N}$ & $\%$ & $\mathbf{N}$ & $\%$ \\
\hline$<3$ & 5 & 4.4 & 0 & 0 & 5 & 2.5 \\
\hline $3-5$ & 10 & 8.9 & 3 & 3.4 & 13 & 6.5 \\
\hline $5-7$ & 31 & 27.6 & 25 & 28.4 & 56 & 28 \\
\hline$\geq 7$ & 66 & 58.9 & 60 & 68.2 & 126 & 63 \\
\hline Total & 112 & 100 & 88 & 100 & 200 & 100 \\
\hline
\end{tabular}

Total Apgar score at 1 min for thick meconium was $<3$ for $5(4.4 \%)$ babies, $3-5$ for $10(8.9 \%)$ babies, $5-7$ for 31 $(27.6 \%)$ babies, $>7$ for $66(58.9 \%)$ babies. Apgar score at 1 min for moderate meconium was $3-5$ for $3(3.4 \%)$ babies, 5-7 for $25(28.4 \%)$ babies, $>7$ for $60(68.2 \%)$ babies. 
Table 7: Distribution of patients according to neonatal complications, $(\mathbf{n}=198)$.

\begin{tabular}{|c|c|c|c|c|c|c|}
\hline \multirow{2}{*}{$\begin{array}{l}\text { Neonatal } \\
\text { complications }\end{array}$} & \multicolumn{2}{|c|}{$\begin{array}{l}\text { Thick, } \\
(\mathrm{n}=110)\end{array}$} & \multicolumn{2}{|c|}{$\begin{array}{l}\text { Moderate, } \\
(\mathrm{n}=\mathbf{8 8})\end{array}$} & \multicolumn{2}{|c|}{$\begin{array}{l}\text { Total, } \\
(n=198)\end{array}$} \\
\hline & $\mathbf{N}$ & $\%$ & $\mathbf{N}$ & $\%$ & $\mathbf{N}$ & $\%$ \\
\hline $\begin{array}{l}\text { Severe birth } \\
\text { asphyxia }\end{array}$ & 5 & 4.5 & 0 & 0 & 5 & 2.5 \\
\hline MAS & 3 & 2.7 & 1 & 1.1 & 4 & 2 \\
\hline HIE & 2 & 1.8 & 1 & 1.1 & 3 & 1.5 \\
\hline $\begin{array}{l}\text { Pulmonary } \\
\text { hemorrhage }\end{array}$ & 1 & 0.9 & 0 & 0 & 1 & 0.5 \\
\hline RDS & 6 & 5.4 & 3 & 3.5 & 9 & 4.5 \\
\hline Septicemia & 3 & 2.7 & 2 & 2.3 & 5 & 2.5 \\
\hline $\begin{array}{l}\text { Total no. of } \\
\text { neonatal } \\
\text { complications }\end{array}$ & 20 & 18.1 & 7 & 7.9 & 27 & 13.6 \\
\hline
\end{tabular}

In our study the overall neonatal complications were severe birth asphyxia (5), MAS (4), septicemia (5), HIE (3), RDS (9) and pulmonary hemorrhage (1).

Table 8: Distribution of patients according to maternal complications, $(n=200)$.

\begin{tabular}{|c|c|c|c|c|c|c|}
\hline \multirow{2}{*}{$\begin{array}{l}\text { Maternal } \\
\text { complications }\end{array}$} & \multicolumn{2}{|c|}{$\begin{array}{l}\text { Thick, } \\
(n=112)\end{array}$} & \multicolumn{2}{|c|}{$\begin{array}{l}\text { Moderate, } \\
(\mathrm{n}=\mathbf{8 8})\end{array}$} & \multicolumn{2}{|c|}{$\begin{array}{l}\text { Total, } \\
(n=200)\end{array}$} \\
\hline & $\mathbf{N}$ & $\%$ & $\mathbf{N}$ & $\%$ & $\mathbf{N}$ & $\%$ \\
\hline PPH & 1 & 0.9 & 2 & 2.3 & 3 & 1.5 \\
\hline $\begin{array}{l}\text { Chorio- } \\
\text { amnionitis }\end{array}$ & 1 & 0.9 & 0 & 0 & 1 & 0.5 \\
\hline $\begin{array}{l}\text { Puerperal } \\
\text { sepsis }\end{array}$ & 0 & 0 & 1 & 1.1 & 1 & 0.5 \\
\hline $\begin{array}{l}\text { Wound } \\
\text { infection }\end{array}$ & 2 & 1.8 & 1 & 1.1 & 3 & 1.5 \\
\hline $\begin{array}{l}\text { Maternal } \\
\text { death }\end{array}$ & 0 & 0 & 0 & 0 & 0 & 0 \\
\hline $\begin{array}{l}\text { Total no. of } \\
\text { maternal } \\
\text { complications }\end{array}$ & 4 & 3.6 & 4 & 4.5 & 8 & 4 \\
\hline $\begin{array}{l}\text { Women } \\
\text { without } \\
\text { maternal } \\
\text { complications }\end{array}$ & 108 & 96.4 & 84 & 95.4 & 192 & 96 \\
\hline
\end{tabular}

Overall, 8 mothers had maternal complications out of which 3 women had PPH. Another 3 patients had wound infection post LSCS; one had chorioamnionitis and one puerperal sepsis. chorioamnionitis, puerperal sepsis, wound infection patients were managed well with higher antibiotics. We had no maternal mortality.

\section{DISCUSSION}

A hospital based observational, prospective study was conducted with 200 patients to evaluate maternal and fetal outcome in MSAF. $112(56 \%)$ patients had thick MSAF while $88(44 \%)$ patients had moderate MSAF.
In present study during November 2017 to August 2019 $13.11 \%$ deliveries had MSAF. In study conducted by Rajput et al $8.98 \%$ deliveries had MSAF. These results are approximately close to each other. ${ }^{9}$

In our study $56 \%$ patients had thick MSAF while $44 \%$ patients had moderate MSAF and in study by Rajput et al $35 \%$ had thick while $21 \%$ had moderately meconiumstained liquor. ${ }^{9}$ Here proportion of both thick and moderate meconium was higher than the study. Unnisa et al shows $44.5 \%$ were thickly Meconium stained. ${ }^{10}$

Our study shows a greater number of women $71 \%$ with MSAF had gestational age 37-40 weeks and 29\% were having gestational age $>40$ weeks. Unnisa et al $41.4 \%$ had gestational ages of 39-39.6 weeks. ${ }^{10}$ Mundhra et al 50\% cases had gestational ages of more than 40 weeks. Here $<40$ weeks gestational age women are more as compared to study. ${ }^{11}$

It was observed in the present study that MSAF was more common in maternal high-risk factors like Post-dated pregnancy $29 \%$, oligohydramnios $19 \%$, pregnancy induced hypertension $16.5 \%$, anaemia 7\%, PROM 5\%, antepartum haemorrhage $2 \%$. Rajput et al observed Oligohydramnios 30\%; PIH 24\%, anaemia 14\%, and antepartum haemorrhage $4 \%$. Results are similar to study of Rajput et al. ${ }^{9}$ Priyadharshini et al post-dated pregnancy (82), PIH (12), Rh isoimmunisation (12), oligohydramnios (9), GDM (8), heart disease (5), higher maternal age (5), chronic respiratory disease (4), teen age pregnancy (3), cholestasis of pregnancy (3). The intra-partum risk factors were prolonged PROM (9), IUGR (8), prolonged labour (3), circumvallate placenta (1), ileal atresia (1), premature atrial contraction of fetus (1). ${ }^{12}$ Mundhra et al PIH seen in $16.97 \% .^{11}$

In the present study, patients who were in active phase of labour (before $7 \mathrm{~cm}$ dilatation of cervix) were $57.5 \%$ and who crossed $8 \mathrm{~cm}$ dilatation of cervix, were $42.5 \%$. In active phase of labour, meconium-stained liquor was detected either with spontaneous or artificial rupture of membrane.

In our study amnioinfusion was done in $38 \%$ patients. Pushpa et al performed trans-cervical intra-partum amnioinfusion in women of MSAF and found that variable decelerations were decreased in $68.18 \%(15 / 22)$ cases in the study group. ${ }^{13}$

In our study, $71.5 \%$ patients had undergone LSCS, $24 \%$ delivered vaginally and instrumental delivery was conducted for $4.5 \%$ patients. LSCS rate was higher because of non-availability of fetal scalp blood testing. In study conducted by Rajput et al most common mode of delivery was caesarean section (83\%) which is similar to present study. ${ }^{9}$ Present study result are higher than to study conducted by Mundhra et al $49.09 \%$ LSCS and $10 \%$ instrumental deliveries. ${ }^{11}$ 
In Unnisa et al $45.7 \%$ had LSCS, Normal deliveries were $49.5 \%$ and approximately $4.8 \%$ cases had instrumental delivery. ${ }^{10}$

We observed that most common indication for LSCS was fetal distress $44.7 \%$. Other indications were abnormal labour 20.3, MSAF in early active labour $27.9 \%$, ante partum hemorrhage $2.8 \%$, IUGR with Doppler changes $3.5 \%$ and cord prolapse $0.7 \%$. This finding was consistent with the studies of Rajput et al having fetal distress $30 \%$, in study of Pushpa et al also fetal distress was most common indication for LSCS $28.5 \% .^{9,13}$

In this study we found 2 fresher still birth babies, so Apgar score of two babies was zero. Total Apgar score at $1 \mathrm{~min}$ for thick meconium was $<3$ for $5(4.4 \%)$ babies, $3-5$ for 10 $(8.9 \%)$ babies, $5-7$ for $31(27.6 \%)$ babies, $>7$ for 66 (58.9\%) babies. Apgar score at $1 \mathrm{~min}$ for moderate meconium was 3-5 for 3 (3.4\%) babies, 5-7 for $25(28.4 \%)$ babies, $>7$ for $60(68.1 \%)$ babies.

Pushpa et al shows 22\% babies with Apgar score $<7$ and $78 \%$ with $>7$ at $1 \mathrm{~min}$. This is in concordance to the study of Pushpa et al. ${ }^{13}$ Pushpa et al prospective comparative study reported Apgar score $<7$ at $1 \mathrm{~min}$ was seen in $22 \%$ cases in the study group. ${ }^{13}$

In our study the neonatal complications in MSAF were severe birth asphyxia $2.5 \%$ with APGAR score at 1 min between 0-3, (it includes two FSB and three NNDs), MAS $2 \%$, septicemia $2.5 \%$, HIE $1.5 \%$, RDS $4.5 \%$ and pulmonary hemorrhage $0.5 \%$. In 3 babies who later developed HIE, it was noted that their mothers were transferred patients from peripheral hospital with long standing meconium as the cord was found to be stained with meconium. Patients with thick MSAF had significantly higher incidence of neonatal complications compared to patients with moderate MSAF. Studies of Pushpa et al 6\% MAS and 6\% severe birth asphyxia ${ }^{13}$ Rajput et al 6\% MAS Priyadharshini et al $40 \%$ developed MAS and $14.28 \%$ had severe birth asphyxia. ${ }^{9,12}$ Present study shows neonatal complications lesser than other studies.

The current study shows that 3 (1.5\%) women had PPH, of which 2 had traumatic PPH after forceps application due to cervical tear and 1 had atonic PPH. Another 3 patients had wound infection post LSCS; one had Chorioamnionitis and one puerperal sepsis. Chorioamnionitis, puerperal sepsis, wound infection patients were managed well with higher antibiotics. We had no maternal mortality. Thick MSAF was associated with more maternal complication than moderate MSAF. we had less maternal complications as compared to study of Pushpa et al having tonic PPH occurred in $8 \%$ women. ${ }^{13}$

\section{Limitation}

In $124(62 \%)$ patients amnioinfusion could not be done as the duration between detection of MSAF and delivery was short. Some patients were already in second stage of labour and delivered normally, few required instrumental delivery to cut short second stage of labour and few underwent LSCS. Limitation of advanced investigations like fetal scalp blood testing.

\section{CONCLUSION}

Early identification of MSAF in labouring women during intra-partum monitoring and availability of operation theatre for immediate intervention is required to reduce the perinatal morbidity and mortality. It is important to register all high-risk patients at tertiary centre with NICU availability. Also, it is mandatory to have NICU facilities in all maternity homes where babies with MSAF are delivered. This study advances our knowledge and understanding in the field of presence of MSAF in terms of need of close monitoring of fetus, mindful intervention, and presence of skilled neonatologist, obstetrician and anaesthetist at the time of birth so as to decrease perinatal morbidity and mortality.

\section{Funding: No funding sources \\ Conflict of interest: None declared}

Ethical approval: The study was approved by the Institutional Ethics Committee

\section{REFERENCES}

1. Locatelli A, Regalia AL, Patregnani C, Ratti M, Toso L, Ghidini A. Prognostic value of change in amniotic fluid color during labor. Fetal diagnosis and therapy. 2005;20(1):5-9.

2. Antonowicz I, Shwachman H. Meconium in health and in disease. Adv Pediatr. 1979;26:275-310.

3. Lucas A, Christofides ND, Adrian TE, Bloom SR, Aynsley-Green A. Fetal distress, meconium, and motilin. Lancet. 1979;313(8118):718.

4. Rossi EM, Philipson EH, Williams TG, Kalhan SC. Meconium aspiration syndrome: intrapartum and neonatal attributes. Am j obstetr gynecol. 1989;161(5):1106-10.

5. Walker J. Foetal anoxia. Int J Obstetr Gynaecol. 1954;61(2):162-80.

6. Ramin KD, Leveno KJ, Kelly MA, Carmody TJ. Amniotic fluid meconium: a fetal environmental hazard. Obstetr Gynecol. 1996;87(2):181-4.

7. James DK, Steer CP, Weiner B. Gonic. High risk pregnancy. $1^{\text {st }}$ edition, Elsevier. 1994;1135-42.

8. Chang MY, Wang SY, Chen CH. Effects of massage on pain and anxiety during labour: a randomized controlled trial in Taiwan. $\mathrm{J}$ advanced nursing. 2002;38(1):68-73.

9. Rajput U, Jain A. Impact of meconium-stained amniotic fluid on early neonatal outcome. J Evolution Med Dental sci. 2013;2(45):8788-95.

10. Unnisa S, Sowmya BS, Rao SB, Rajagopal K. Maternal and fetal out come in meconium-stained amniotic fluid in a tertiary centre. Int $\mathrm{J}$ Reprod Contrac Obstetr Gynecol. 2016;5(3):813-7. 
11. Mundhra R, Agarwal M. Fetal outcome in meconiumstained deliveries. $\mathrm{J}$ clin diagnostic res. 2013;7(12):2874.

12. Priyadharshini M, Panicker S. Meconium-stained liquor and its fetal outcome-retrospective study. IOSR-JDMS. 2013;6(2):27-31.

13. Bhatia P, Reena K, Nangia S. Role of intrapartum transcervical amnioinfusion in patients with meconium-stained amniotic fluid. J Obstetr Gynecol India. 2013;63(1):59-63.

Cite this article as: Dandale AU, Bava AK, Shinde NR. A study of maternal and fetal outcome in meconium-stained amniotic fluid-a prospective hospital-based study. Int J Reprod Contracept Obstet Gynecol 2021;10:4499-507. 


\section{ANNEXURE A}

\section{Case record form}

Patient's age

Parity

Booking status

Gestational age

Maternal risk factors

Ultrasonography findings

Examination: Cervical dilatation

Active phase/ transition phase

Color of meconium-stained liquor: Thick / moderate

Amnioinfusion received or not

Maternal outcome

Mode of delivery: vaginal, instrumental, caesarean section.

If caesarean, indication: maternal indication

Fetal indication

Any puerperal complications

Fetal outcome

Apgar at $1 \mathrm{~min}$, neonatal complications 


\section{ANNEXURE B}

\section{List of abbreviations used}

AF: Amniotic fluid,

MSAF: Meconium-stained amniotic fluid,

LSCS: Lower segment caesarean section,

IUGR: Intra uterine growth restriction,

MAS: Meconium aspiration syndrome,

RDS: Respiratory distress syndrome,

HIE: Hypoxic ischaemic encephalopathy,

NICU: Neonatal intensive care unit,

PIH: Pregnancy induced hypertension,

PROM: Premature rupture of membranes

PPHN: Persistent pulmonary hypertension

PPH: Post-partum haemorrhage. 